\title{
Health Promotion Strategy for Improving Men's Participation in Family Planning Program in the Underdeveloped Areas, Borders and Islands and Poor Urban Areas
}

\author{
Indah Eka Novita ${ }^{1}$, Lutfi Agus Salim ${ }^{2}$ \\ ${ }^{1}$ Undergraduate Student in Department Biostatistic and Demography, Faculty of Public Health, Universitas \\ Airlangga, Surabaya, Indonesia, ${ }^{2}$ Associate Profesor in Department Biostatistic and Demography, Faculty of \\ Public Health, Universitas Airlangga, Surabaya, Indonesia
}

\begin{abstract}
The participation of men in family planning in Indonesia is still very low, where the men who use the Medical Male Operations (MOP) method are only $0.2 \%$ while the condom use is 3.1\% (IDHS 2017), Likewise in East Java only $3.7 \%$ of the total new KB participants in 2019. The conditions most in need of attention are in underdeveloped areas, borders, islands and poor areas, which are in dire need of appropriate strategic breakthroughs. The conditions most in need of attention are underdeveloped areas, borders, islands and poor areas, which are in need of appropriate strategic breakthroughs. Strengthen the advocacy efforts for new regional leaders so that the family planning program can continue to run in the regencies/cities without having to start from zero again, provide training to male family planning motivators so that the information provided to prospective acceptors is more detailed and accurate and follows up the results of training of medical personnel and midwives.
\end{abstract}

Keyword: Men's participation in family planning, Health promotion strategies.

\section{Introduction}

The development of a nation is closely related to population problems. One indicator of the success of the nation's development is said to be achieved if it is supported by the subject of development, namely residents who have optimal quantity and quality ${ }^{(1)}$.

East Java Province is used as a pillar and a buffer for the implementation of the national family planning program which is run by all provinces in Indonesia. Even though it has been called a buffer zone, the challenges of implementing the family planning program remain ${ }^{(2)}$. The population of East Java which is predicted to reach 40 million this year and also the decentralized system is a small obstacle to the implementation of the program in East Java Province ${ }^{(3)}$.

FP programs that have been running for almost 40 years in Indonesia must pay more attention to the issues of justice and gender equality after the ratification of the Cairo Declaration ${ }^{(4)}$. This certainly also had an impact on the family planning program. The level of family planning participation in general is still dominated by women. The number of male FP participation is still very low. The active participants of male birth control using the Medical Operation Method for men (MOP) are only $0.2 \%$ while the use of condoms is $3.1 \%{ }^{(5)}$ while in East Java the numbers are only 3.7\% of the total new FP participants until November 2019. Thus the number of male family planning participation in the province of East Java is still low.

In order to deal with the problem of male birth control, the BKKBN has a Directorate of Family Planning Participation in the Regional Path and Special Targets. This directorate was formed to increase male participation in family planning programs and also reach special areas that are included in underdeveloped, border and island areas and also urban poor areas ${ }^{(6)}$.

Based on the various reasons above, an analysis of the Family Planning Program for Men in Underdeveloped, Border and Islands and urban poor areas is needed in the BKKBN Representative of East Java Province to 
see efforts to increase the participation of male family planning, especially in the province of East Java

\section{Method}

This research uses quantitative research method with a secondary data analysis approach. This study uses data sourced from the BKKBN monthly report and also the policy for the implementation of the BKKBN Men's FP. Analysis was also carried out on policies relating to the implementation of male birth control in East Java, specifically at Underdeveloped, Border and Island areas (UABI) and also urban poor areas.

\section{Result}

Overview of Achievement of Men's FP Program in Underdeveloped, Border and Islands and Urban Poor Areas in East Java Province: As one of the buffer zones of family planning programs in Indonesia, East Java Province through its BKKBN Representative routinely reports on the achievements of the program each month, including the Male FP program.

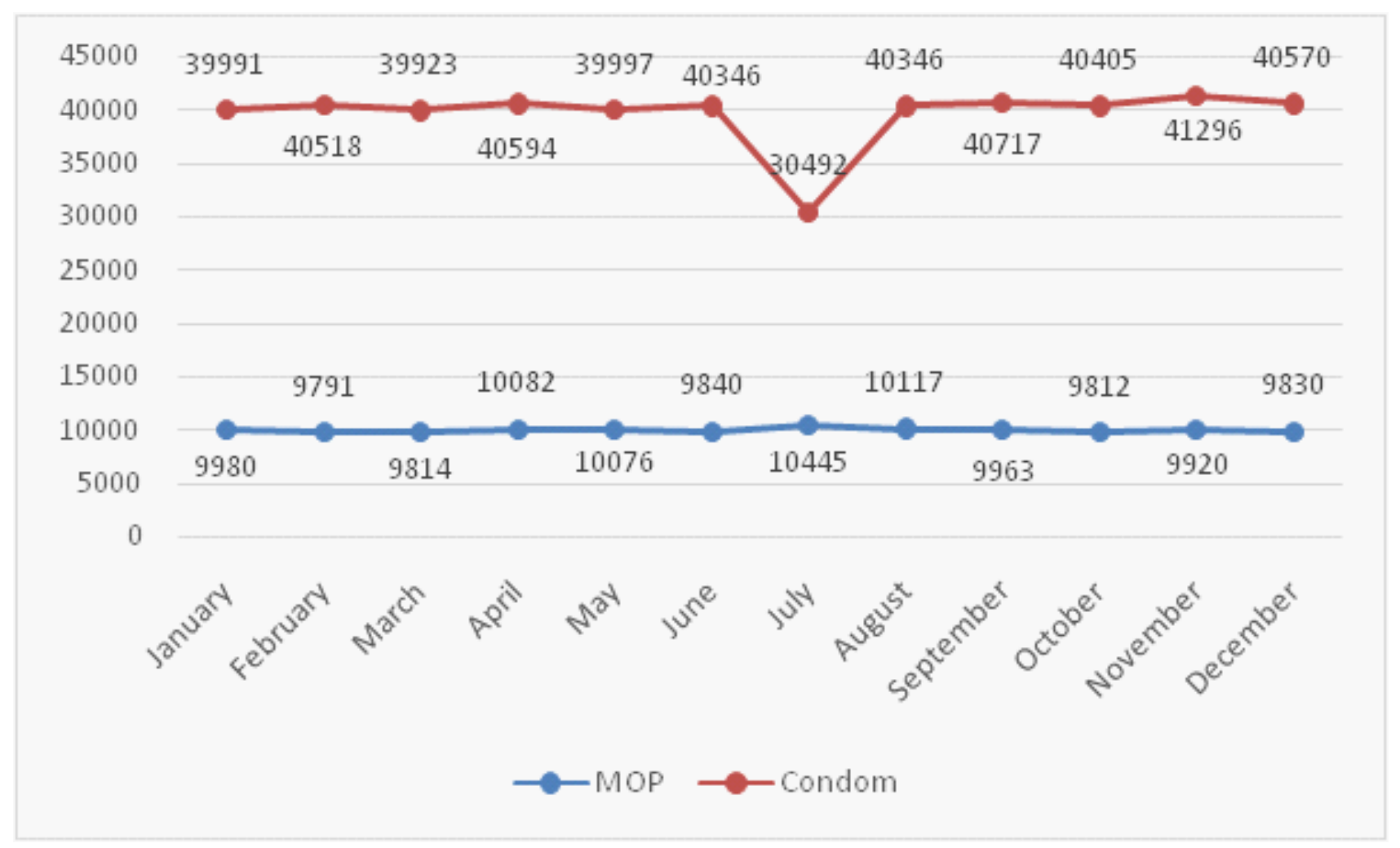

Figure 1: Trends in Active Family Planning Participants in UABI and Urban Poor Areas in East Java Province 2019

Figure 1 show that the tendency of PA is quite stable, but in the condom method there was a decrease in users in July. This shows an increase in the rate of discontinuation of condom contraception in July. 


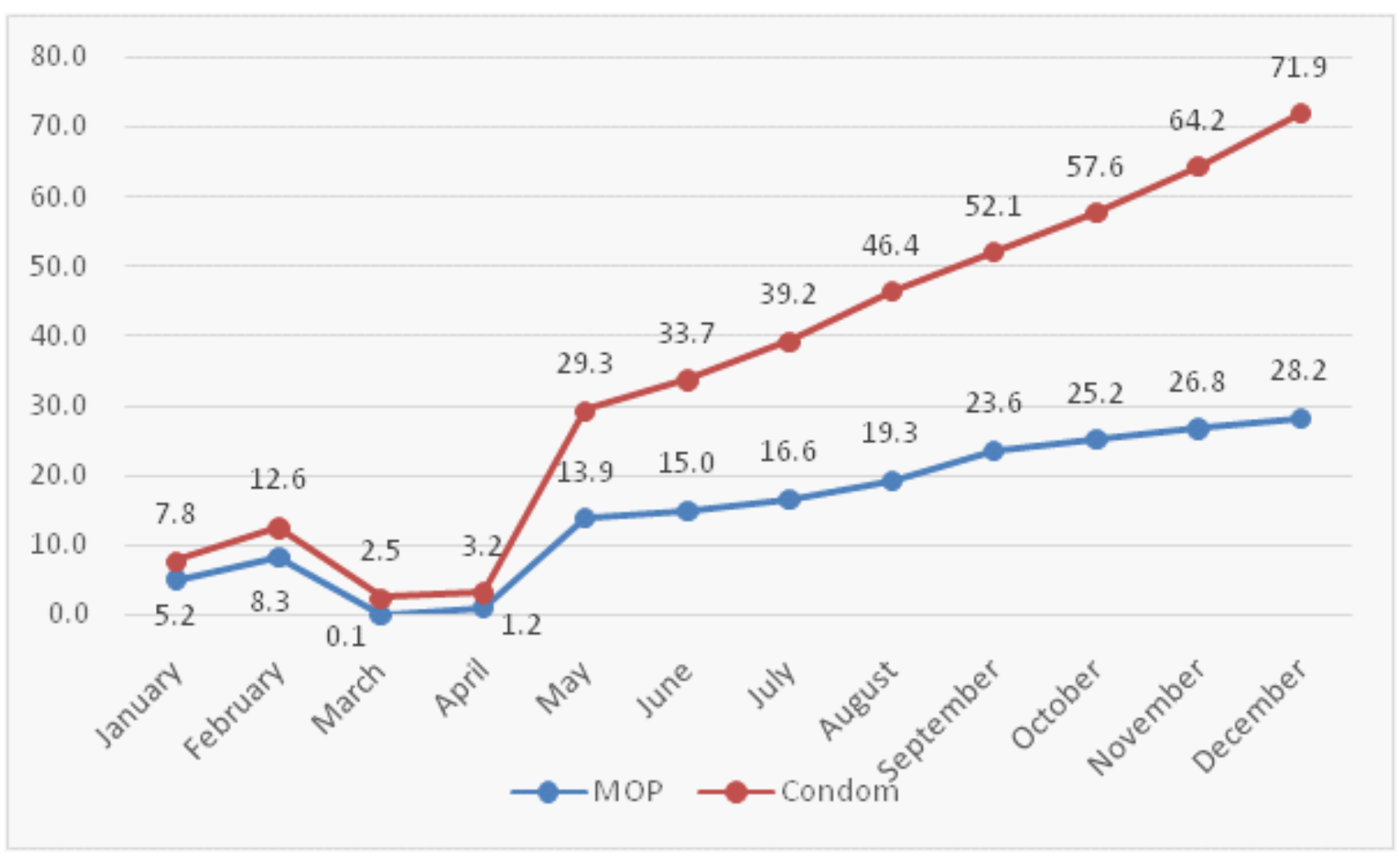

Figure 2: Results of Achievement of New Male FP Participants in UABI and Urban Poor Areas in East Java Against 2019's Targets

Targets data used is MOP and Condom PPM data that must be achieved by every Regency/City in East Java, including UABI and urban poor areas. PPM data used is MOP and Condom PPM data that must be achieved by every Regency/City in East Java, including UABI and urban poor areas. Achievement results that continue to increase are quite good and indicate improvements in each month, but when viewed from the figures, the results are still unsatisfactory especially in the MOP method which until the end of the year only reached $28.2 \%$ of the target set by the central government.

\section{Discussion}

Health Promotion Strategy: Health promotion aims to promote health programs in order to realize a new Indonesian society that is cultured with a clean and healthy life and participates directly in the health movement. To achieve the goal of realizing health promotion, a good strategy is needed. Strategy is a way to achieve and realize the vision and mission of health effectively and efficiently ${ }^{(7)}$.

To achieve the goal of realizing health promotion, a good strategy is needed. Strategy is a way to achieve and realize the vision and mission of health effectively and efficiently. Decree of the Minister of Health Number 1193/ Menkes/SK/X/2004 regarding the National Health Promotion policy and Decree of the Minister of Health Number 1114/Menkes/SK/VII/2005 Regarding the Guidelines on the Implementation of Health Promotion in the Regions ${ }^{(8)}$. The strategies needed to realize health promotion are as follows:

Advocacy: Advocacy is an effort or a strategic and planned process with the aim of getting commitment and support from the parties concerned ${ }^{(9)}$. The aim of this health advocacy is to increase the number of health-oriented public policies, to increase public opinion in supporting health and to solve health problems together and integrated with regional health development through partnerships and the support and care of regional leaders ${ }^{(10)}$. The targets of health advocacy are decision makers as well as policies at the provincial, city or district level, as well as at the central level. For health advocacy activities, it consists of various forms, both formal and informal. 
Government support for the Men's FP program is one of them manifested by the support of policies that favor the implementation of the Men's FP in UABI and urban poor areas ${ }^{(11)}$.

\section{Supporting policies include:}

1. Constitution No. 52 Year 2009 About Population Development and Family Development

2. Constitution No. 1 Tahun 2014 about Changes of Constitution No. 27 Year 2007 About Management of Coastal Areas and Small Islands.

3. Presidential Republic of Indonesia Regulation No. 78 Year 2005 About the Management of the Outermost Islands

4. Regulation of the Head of BKKBN Number: 82/ PER/B5/2011 About the Organization and Work Procedure of the Provincial National Population and Family Planning Agency Representative.

5. Regulation of the Head No.10 Year 2018 About the Implementation of Mobile Family Planning Services

6. Goverment Regulation No. 87 Year 2014 About Population Development and Family Development, Family Planning and Family Information Systems.

7. Presidential Republic of Indonesia Regulation No. 82 Year 2018 regarding Health Insurance in article 52 describes health services not guaranteed by Health Insurance.

BKKBN Representatives of East Java Province each year formulate a Work Plan which will later be advocated to the Central BKKBN in order to get support and approval. Besides that, they also routinely hold Regional Work Meetings with all representatives of Regencies/Cities in East Java Province to discuss work programs and plans for the next year's activities.

Social Support: Health promotion will be easy to do if you get social support. Social support is an activity with the aim of seeking support from various elements (community leaders) to bridge the health program implementers with the community as recipients of the health program ${ }^{(12)}$. The main target of social support or community development is community leaders at various levels (secondary targets), while for other social support or community development targets consist of health care groups, religious leaders, health professionals, health service institutions, mass organizations, community leaders, mass media groups and non-governmental organizations $^{(13)}$.

One of the ways to bring access closer is manifested by the existence of mobile family planning services. This mobile family planning service is based on conditions in regions where health facilities are not yet available that meet the requirements, there are no competent medical personnel available, areas that require assistance with mobile family planning services such as in the context of social service activities and the like ${ }^{(12)}$.

BKKBN Representatives of East Java Province through cooperation in the Field of FP-RH have routinely held Mobile FP Services through service visits and also use mobile FP service facilities or commonly referred to as "Muyan KB".

One of the most important things in conducting Mobile Family Planning Services is the presence of competent doctors or midwives. The presence of competent medical personnel is very influential in service in the field, so this must continue to be optimized. Of $161 \mathrm{MOP}$ doctors/providers who have been trained in 2012-2015, only 34 doctors/providers have been able to serve MOP, in other words only $21 \%$. This certainly will greatly affect the achievement of male birth control especially with the MOP method in East Java.

Community Empowerment: Empowerment is a process of providing information to families or groups and individuals continuously and continually ambungan by following the development of the community and the process of helping the community so that the community changes from being ignorant to knowing or aware and from knowing to being willing and from wanting to be able to implementing the introduced health $\operatorname{program}^{(14)}$. There are two health promotion objectives that are linked to community empowerment. First, empowerment is a way in which the community is expected to be able to carry out their lives. Second, it can improve healthy living behavior in the community and third, it can increase the role of the community in health efforts ${ }^{(10)}$.

Community empowerment related to male family planning is a motivator for male family planning and also male family planning groups. Male Family Planning Motivators are those who have used MOP contraception method in their environment and are expected to become MOP acceptors in their experience and can invite people around to keep the same things. The Male FP Motivator is in charge of communicating the existing 
Male FP Program to the people in his neighborhood, providing information related to the Male FP Program and educating the surrounding community about the same thing. The male family planning motivator is also an extension of the BKKBN in the community so that its presence can be felt by all levels of society, especially those in disadvantaged areas, borders and islands as well as urban poor areas. At present, East Java Province has 199 FP Family Motivators.

It is different only with the male FP group, this group is an association of men who have used the MOP contraceptive method. The purpose of the formation of this group is so that fellow acceptors can update information related to the impacts and effects of using MOP method. In addition, the acceptor can also find answers to the obstacles that might occur in him. At present, East Java Province has 127 male family planning groups.

Partnership: In empowerment, community development and advocacy, the principles of partnership must be upheld ${ }^{(15)}$. Partnerships are developed between health workers and their targets,and developed because of the awareness that to improve the effectiveness of health promotion. Health workers must collaborate with various related parties, such as professional groups, religious leaders, NGOs, mass media, etc.

Partners are needed in the continuity of the family planning program. Therefore, the BKKBN collaborates with several parties to support the acceleration of achieving the KB program targets. These institutions include:

a. Partnership with Indonesian National Army

b. Ministry of Villages Development of Underdeveloped Regions and Transmigration Synergy of the KKBPK Program in the Village Fund for the KB Program; The use of Village Funds in supporting the availability of $\mathrm{KB}$ Extension Offices and Improving the economy through the productive capital of the local community; KB CIE and Reproductive Health in Disadvantaged Areas and Transmigration by involving transmigration instructors at the time of debriefing prospective transmigrants; Family Planning and Reproductive Health services in health facilities in transmigration areas.

c. Ministry of Maritime Affairs and Fisheries: Conducting advocacy and IEC and KKBPK program services and the movement to promote fish eating for the community; Community empowerment and resource utilization on the coast and small islands towards prosperous families, especially in the FP Village; Exchange of data and information; Joint utilization of supporting facilities and infrastructure; Increasing access and quality of family planning and family planning; Facilitating increased use of long-term contraceptive method through fisheries counselors; Promote family planning and family planning programs and family planning services.

d. Partnership with Interfaith Forum for Religion Cares About Family Welfare and Population

e. Perkumpulan Kontrasepsi Mantap Indonesia (PKMI) Vasectomy and Tubectomy training for doctors; Provide medical assistance/visiting specialists during vasectomy services; Giving material for male birth control Ikatan

f. Partnership with Indonesian Urologist

g. Indonesian Population Coalition East Java Provinceto assist scientific studies of advocacy and policy analysis

h. Indonesian Ulama Council, to assistance about the rumor of a vasectomy male birth control

i. National Disaster Management Agency IEC about FP and Health; Reproduction through information media; Provision of contraceptive devices and medicines in disaster conditions; Family Planning Services in the affected areas.

j. Head of Regional Apparatus Organization FP

If described the health promotion strategy in increasing men's participation in family planning is as follows (8): 


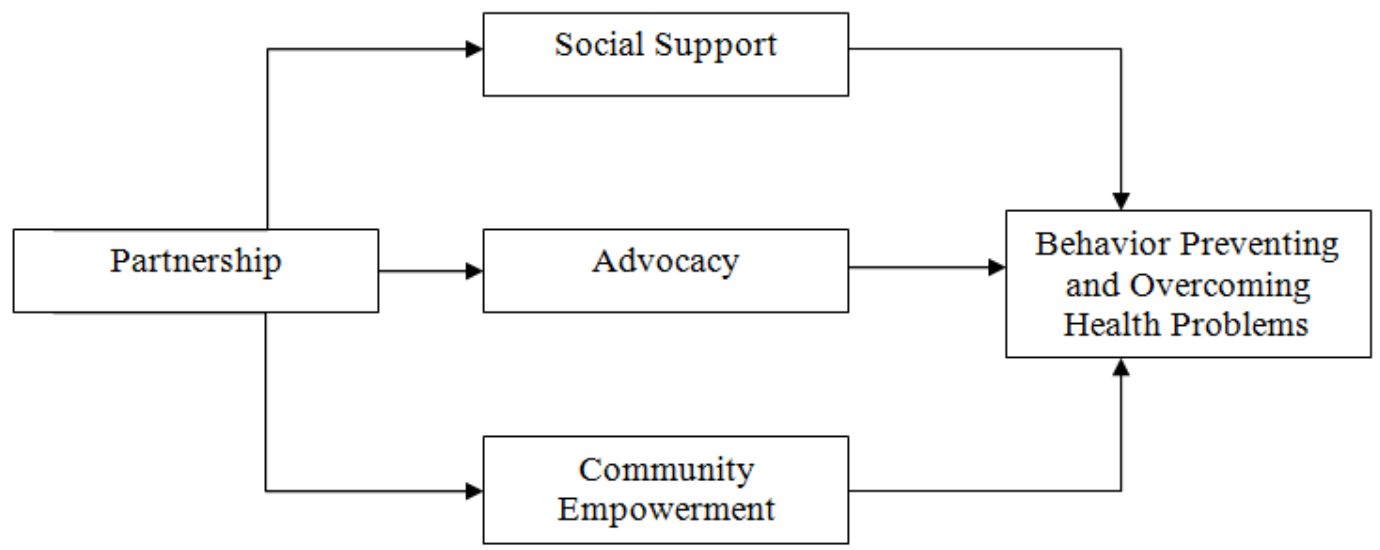

Figure 3: Health Promotion Strategy Chart

\section{Conclusion}

The results of the analysis of the Men's Family Planning Program in Underdeveloped, Border and Islands and urban poor areas in the BKKBN Representative of East Java Province, can be concluded as follows:

1. Advocacy has been carried out with the support of policies from the central government, cross-sectoral, as well as the head of the agency namely BKKBN. BKKBN has also routinely drawn up work plans and held regional work meetings

2. Community development has been carried out by bringing access to family planning services closer to areas in need (Underdeveloped, Border and Islands and urban poor areas). Efforts made by way of service visits and using mobile FP service facilities (Muyan KB)

3. Community empowerment is done through the formation of motivators for male birth control and also for male birth control groups

4. Partnerships are needed to optimize efforts to improve men's participation in family planning, especially in specific areas. Partnerships that have been established, among others professional groups, religious leaders, NGOs, mass media, etc.

\section{Recommendation:}

1. Strengthen advocacy efforts for new regional leader candidates so that the KB program can continue to run in the Regency/City without having to start from scratch again

2. Provide training to male family planning motivators so that the information provided to prospective acceptors is more detailed and accurate

3. Register the reasons for doctors/providers who have been trained but do not want to provide services so they can be followed up again.

Conflict of Interest: The authors have no conflict of interest with the material presented in this paper

\section{Sources Of Funding: NILL}

Ethical Clearance: NILL. My paper is an idea and policy analysis to solve population problems, without any treatment to the respondent/informant

\section{Reference}

1. Heryani D, Mardiansjah FH. Pemberdayaan Ekonomi Produktif Dalam Penanggulangan Kemiskinan Perdesaan di Kabupaten Rembang. JURNAL PEMBANGUNAN WILAYAH \& KOTA. 2017;13(1):14-26.

2. Bunu HY. Resistensi Daerah Terhadap Program Keluarga Berencana. PIRAMIDA. 2018;XIV(1):115.

3. Bappenas, Central Bureau of Statistics, UNFPA. Indonesian Population Projection 2010-2045. Jakarta: Central Bureau of Statistics; 2013.

4. United Nations. Report of the International Conference on Population and Development Cairo, 5-13 September 1994. 1995.

5. National Population and Family Planning Board Indonesia, Statistical Indonesia, Ministry of Health, ICF. Indonesia Demographic and Health Survey 
2017 [Internet]. Jakarta, Indonesia: BKKBN, BPS, Kemenkes and ICF; 2018. Available from: http:// dhsprogram.com/pubs/pdf/FR342/FR342.pdf

6. Senewe FP, Elsi E. Analisis deskriptif kesehatan lingkungan di daerah tertinggal, perbatasan, kepulauan dan terpencil (DTPK-T). Media Litbangkes. 2014;24(3):153-60.

7. Tiraihati ZW. Analisis Promosi Kesehatan Berdasarkan Ottawa Charter Di RS Onkologi Surabaya. Jurnal Promkes. 2017;5(1):1-11.

8. Rodiah S, Rosfiantika E, Yanto A. Strategi Promosi Kesehatan Puskesmas DTP Tarogong Kabupaten Garut.

9. Johnson S. Challenges in health and development: From global to community perspectives. Springer. 2011. 1-196 p.

10. Setyabudi RG, Dewi M. Analisis Strategi Promosi Kesehatan dalam Rangka Meningkatkan Kesadaran
Hidup Sehat oleh Rumah Sakit Jiwa Daerah. Jurnal komunikasi. 2017;12(1):81-100.

11. Mahardini DA, Suranto J. Implementasi Kebijakan Operasional Peningkatan Partisipasi Pria Dalam Program Keluarga Berencana DI Kelurahan Gilingan Kecamatan Banjarsari Kota Surakarta. Ji@P. 2018;5(1):108-24.

12. Mayo M.Cultures, communities, identities: Cultural strategies for participation and empowerment. Springer; 2000.

13. Caples J. Tested advertising method. Univerza $\mathrm{v}$ Mariboru, Ekonomsko-poslovna fakulteta; 1997.

14. Laverack G. Health promotion practice: building empowered communities. McGraw-Hill Education (UK); 2007.

15. Yuningsih R. Strategi Promosi Kesehatan dalam Meningkatkan Kualitas Sanitasi Lingkungan. Jurnal Masalah-Masalah Sosial. 2019;10(2):10718. 